\title{
The Civil Code of the People's Republic of China: Major Features and Contributions to the World*
}

\author{
LI Shaohua \\ Party School of Wuhan Municipal Party Committee of CPC, Wuhan, China \\ XIAO Peng \\ Zhongnan University of Economics and Law, Wuhan, China
}

\begin{abstract}
After decades of preparation, China ultimately enacted the Civil Code of the People's Republic of China, and this Code exerts significant influence on the international community. The Code is distinguished from civil codes of other countries by its philosophy of codification, structure, systems, principles, and specific provisions. Revolving around civil rights stipulated in the Civil Code, this article selects and analyzes a portion of provisions to throw light on the real right system's characteristics of the era and of China. This paper aims to underline the importance of laying special emphasis on maintaining personal dignity, and discuss the necessity of actively adapting laws for the development of extensive IT application. This paper sets forth how the part on contracts functions as general provisions of the part on the law of obligations and how the part on tort liability protects all the rights enshrined in the preceding six parts, as well as the ensuing advantages. This paper also clarifies the features of the Civil Code, and summarizes the unique contributions made by the Civil Code to the world.
\end{abstract}

Keywords: Civil Code, real rights, personality rights, contracts, tort liability

\section{Introduction}

On May 28, 2020, the Civil Code of the People's Republic of China (hereafter referred to as the "Civil Code") was passed at the third session of the 13th National People's Congress. The Civil Code is comprised of 1,260 articles in seven parts, namely, general provisions, real rights, contracts, personality rights, marriage and family, succession and tort liability, as well as supplementary provisions. The Civil Code is the first Chinese law that is titled "code" after the People's Republic of China (PRC) was founded. It blazes a trail in the field of code codification in China, and therefore is widely acclaimed as a milestone in the development of China's legal system. ${ }^{1}$

\footnotetext{
* Acknowledgements: This research is supported by "the General Research Funds of the 2019 Hubei Provincial Plan for Education Sciences" (Grant Number 2019GB012) and "the Fundamental Research Funds for the Central Universities (Scientific Research Cultivation) Class C", Zhongnan University of Economics and Law (Grant Number 73).

LI Shaohua, Ph.D. in Law, editor in charge, Party School of Wuhan Municipal Party Committee of CPC, Wuhan, China.

XIAO Peng, Corresponding author, Ph.D. in Law, associate professor, School of Foreign Studies, Zhongnan University of Economics and Law, Wuhan, China. E-mail: xiaopeng@zuel.edu.cn.

${ }^{1}$ Explanatory notes to the Civil Code of the People's Republic of China (draft) made by Wang Chen, vice chairman of the National People's Congress Standing Committee at the third session of the 13th National People's Congress on May 22, 2020.
} 
The Civil Code is highly informative and illuminating, and is codified based on an advanced philosophy. This Code features a seven-part structure, a unique codification system, and a separate part devoted to personality rights. It has also laid down principles peculiar to the Code, such as the green principle, the principle of family solidarity, and code of ethics of a family. An examination of the Civil Code is, therefore, of profound significance. Nonetheless, this article centers on people's civil rights instead of their property. On the basis of the seven-part structure, characteristic ideas, systems and provisions are picked out and delved into, and the Civil Code's major characteristics and its contributions to the globe are illuminated. To be specific, representative ideas, systems, and provisions can be encapsulated in five aspects: a unique codification system, the real right system's characteristics of the era and of China, a trail-blazing act of dedicating an independent part to personality rights, the part on contracts playing the role of general provisions of the part on the law of obligations, and the part on tort liability providing protection for all the rights established in the preceding six parts.

\section{It Can Be Observed From the Codification System Which Pivots Around Rights That the Civil Code Puts People First}

As an encyclopedia of life, a civil code is supposed to respond to people's diverse needs, the need for enriching the system of rights in particular, so that they can live a better life in the new era (Zhang, 2018). Therefore, the codification of the Civil Code should be centered on and underpinned by rights.

\section{The Influence Wielded by the Structures of Civil Codes of Civil Law Countries on China's Civil Code}

At present, there are two main types of classic civil code systems adopted by civil law countries. The first type is Roman law which is made up of three parts, namely, law of persons, law of things, and procedure law. The second type is German law which is composed of five parts, namely, general part, law of obligations, law of property, family law, and law of succession. The second one is the most influential system in civil law countries.

The codification of civil codes in Modern China dates back to the legal reforms in the late Qing Dynasty, marked by the formulation of the Draft Civil Code of the Great Qing Dynasty ${ }^{2}$ in 1911 . Unfortunately, this draft was never ratified and came into force. Between 1929 and 1930, the Civil Code of the Republic of China ${ }^{3}$, also known as the first civil code in China's history, was drawn up and promulgated. This code adopts a five-part structure, similar to that of the German Civil Code ${ }^{4}$, and the five parts are general part, law of obligations, law of property, family law, and law of succession.

In terms of the number of articles, the German Civil Code and the Napoleonic Code, or the Civil Code of the French ${ }^{5}$ have respectively 2,385 and 2,281 articles, and therefore the Civil Code has more than 1,000 fewer articles than the two. The German Civil Code and the Civil Code of the French were set down two centuries ago. During the past two hundred years, the international situation and the Chinese economy and society have

2 《大清民律草案》, or the Draft Civil Code of the Great Qing Dynasty, was accomplished in 1911.

3 《中华民国民法典》, or the Civil Code of the Republic of China, was promulgated between 1929 and 1931 by the Kuomingtang government.

${ }^{4}$ Bürgerliches Gesetzbuch (BGB), or the German Civil Code, went into effect in the German empire in 1900. It was modified a few times and remains in effect in present-day Germany.

${ }^{5}$ Code Civil des Français, or Civil Code of the French, was established under the French Consulate in 1804 and is still in force. 
undergone profound changes, as a result of which social relations have become more sophisticated and the Chinese people are keener on living a better life. As has been mentioned, however, the Civil Code has over 1,000 fewer articles than its German and French counterparts and should be gradually enriched over time. This Code has only been preliminarily systematized and is far from being an all-round, modern, and international code; therefore it is still at its preliminary stage.

\section{The Civil Code's Innovations in Structure and Their Value}

The Civil Code boasts three notable innovations in organization. First, provisions on personality rights for the first time obtain a standalone part. Second, the part on contracts assumes the role of general provisions of the part on the law of obligations. Third, the part on tort liability also gains its standalone status (Wang, 2020). The value of these innovations lies in the following aspects.

First, the Civil Code is systematized rigorously. The Civil Code revolves around people's rights. The part on general provisions in fact has extracted common factors by framing the most abstract and highly generalized rules pertaining to subjects of civil rights, ways of exercising civil rights, objects of civil rights, and types of civil rights. The part on general provisions stipulates subjects of civil rights with parties to civil legal relations and the following six parts specify other aspects of civil rights: (1) The part on real rights protects real right contracts; (2) the part on contracts protects creditor's rights; (3) the part on personality rights recognizes and protects personality rights; (4) the part on marriage and family acknowledges and protects personal rights regarding marriage and family; (5) the part on succession recognizes and protects inheritance rights; (6) the part on tort liability recognizes tort liability and imposes liability on parties responsible for the harm. In conclusion, the Civil Code is a scientifically-based system that has been constructed with civil rights at its core.

Second, the Civil Code is codified in a logical order-from rights to remedy. As a legal maxim goes, for every right, there is a remedy. The part on tort liability provides relief for victims whose civil rights, as stipulated in all the foregoing chapters, have been infringed. It can be concluded that the logical arrangement guarantees that the part on tort liability provides further protection to all the civil rights set down in the previous parts.

Third, the Civil Code gives prominence to humanistic care. The Civil Code not only reflects the idea of judicial support but also reinforces the value and spirit of humanistic care. Two parts of the Civil Code are devoted respectively to personality rights and tort liability to further preserve personal dignity and protect the property and life of parties to civil legal relations. Traditional civil laws, especially those represented by the German Civil Code, dedicate the bulk of articles to property protection, thereby resulting in a serious persistent defect in the legal system - property is overvalued while people are undervalued. By comparison, the Civil Code remedies this systemic defect by granting the part on personality rights and the part on tort liability standalone status, which further embodies the philosophy of putting people first.

An understanding of the special organization of Civil Code and its value prompts us to change traditional thinking on civil laws and elevate the system of concepts in civil laws to new heights. On that basis, new problems will be identified, new concepts put forward, new rules established, new systems built, and new characteristics highlighted (Zhang, 2018). 


\section{The Civil Code Exhibits the Real Right System's Characteristics of the Era and of China, and Fully Safeguards People's Property Rights and Interests}

Real right relations are different from personal relationships. Different countries' provisions on personal relationships tend to be similar but those on property protection are closely connected with a country's social system, history and traditions, and cultural values. Consequently, real right systems vary greatly from country to country and one country's values regarding real rights may even be distinct from those of another country. The author opines that the Civil Code of the PRC has a comparatively detailed and complete part on real rights, and this part has its features.

\section{The Real Right System's Features of the Era}

First, what is under the regulation of the real right system is unique. As is written in Article 205 of the Civil Code, "This Part regulates civil relations that arise out of the attribution and use of property". It can be inferred that property issues include who should property be attributed to and how to use property. In the light of the attribution and use of property in modern society, the separation of the two issues is very common. When one party to real right relations hands over his or her property to the other party for use, both parties must have given consent to this action on an equal footing because both of them can derive benefit from it. Therefore, the attribution and use of property are also equal and mutually beneficial.

Second, the real right system stipulates unique objects of real rights. The Civil Code does not define "thing" specifically so that objects of real rights are not restricted to traditional physical objects. In this new era, social wealth becomes increasingly diverse and no longer mainly takes the form of physical objects. Instead, social wealth in the form of monetary value becomes more and more important. Therefore, "things" can be interpreted as immediately disposable property interests. This can also be testified by provisions in the Civil Code. For instance, the Civil Code protects data and network virtual property. ${ }^{6}$ Additionally, the part on real rights protects property posted as security ${ }^{7}$, mortgaged property ${ }^{8}$, pledged property ${ }^{9}$, and property under lien ${ }^{10}$. The section on pledge of rights also protects rights that can be pledged, including existing and anticipated accounts receivable. ${ }^{11}$

\footnotetext{
${ }_{7}^{6}$ Article 127 stipulates that where any laws provide for the protection of data and online virtual assets, such laws shall apply.

7 Article 386 stipulates that the security interest holder shall, in accordance with the law, have the priority of compensation made from the property posted as security if the debtor fails to pay the due debt or falls under any circumstance where security interest shall be exercised as agreed upon by the parties, except as otherwise provided for by any law.

${ }^{8}$ Article 394 stipulates that where, for securing the performance of an obligation, the debtor or a third party mortgages a property to the creditor instead of transferring the possession of such a property, if the debtor fails to pay the due debt or falls under any circumstance where mortgage shall be exercised as agreed upon by the parties, the creditor shall have the priority of compensation made from such a property.

9 Article 425 stipulates that where, for securing the performance of an obligation, the debtor or a third party pledges the movable thereof to the creditor for possession, if the debtor fails to pay the due debt or falls under any circumstance where pledge shall be exercised as agreed upon by the parties, the creditor shall have the priority of compensation made from such a movable. For the purposes of the preceding paragraph, the debtor or the third party is the pledgor, the creditor is the pledgee, and the delivered movable is the pledged property.

${ }^{10}$ Article 447 stipulates that where the debtor fails to pay the due debt, the creditor may exercise a lien over the legally possessed movable of the debtor, and has the priority of compensation made from such a movable. For the purposes of the preceding paragraph, the creditor is the lienholder, and the possessed movable is the property under lien.

11 Article 440 stipulates that the following rights that the debtor or a third party is entitled to dispose of may be pledged: (1) bills of exchange, promissory notes and checks; (2) bonds and certificates of deposits; (3) warehouse receipts and bills of lading; (4) transferable fund shares and stock rights; (5) transferable property rights among intellectual property rights, such as the right to the exclusive use of registered trademarks, patents, and copyrights; (6) existing and anticipated accounts receivable; and (7) other property rights which may be pledged as provided for by laws and administrative regulations.
} 
Nevertheless, the aforementioned provisions still have flaws. It can be observed based on an examination of relevant provisions that "thing" and "real right" are respectively still or basically deemed as a thing itself and merely a right that is attached to a thing, rather than a type of resource, especially a scarce resource.

Third, the real right system establishes unique usufruct. Both the part on real rights of the 1898 Japanese Civil Code ${ }^{12}$ and the part on rights in Rem of the Civil Code of the Republic of China apply usufruct only to immovables, while the part on real rights of the Civil Code of the People's Republic of China stipulates that a usufructuary can exercise usufruct over not only immovables but also movables ${ }^{13}$. This change means that the Civil Code expands the scope of usufruct, thus laying a foundation for the creation of usufruct over movables. The usufruct over movables embraces financial leasing, security funds, trust, and other new social relations of property use. Furthermore, the part on real rights defines explicitly the use of natural resources as a type of usufruct $^{14}$, another hallmark of usufruct in the Civil Code.

Fourth, the real right system stipulates unique security interests. The part on real rights breaks through the scope of security of the Property Law of the $\mathrm{PRC}^{15}$ and the Guaranty Law of the PRC ${ }^{16}$ which were promulgated before the Civil Code. Contracts on the provision of security encompass not only mortgage contracts and pledge contracts, but also other types of contracts with security functions. ${ }^{17}$ As a result, the expansion of security interests and diversification of modes of security are facilitated, and the modernization of modes of security is reflected.

\section{The Real Right System's Chinese Characteristics}

As has been elucidated, a country's state system and system of government determine its real right system; hence the real right system is not widely applicable. China's real right system foregrounds the advantages and earmarks of the basic socialist economic system with Chinese characteristics, which can be illustrated from the following six aspects.

First, the Civil Code provides for three forms of ownership, namely, state ownership, collective ownership, and private ownership, and states clearly that the ownership of different parties to civil legal relations shall

\footnotetext{
12 《民法》, or the Japanese Civil Code, was adopted in 1898. It was modified after the Second World War and remains in effect in present-day Japan.

${ }_{13}$ Article 323 stipulates that a usufructuary shall, in accordance with the law, have the right to possess, use, and seek profits from the immovables or movables owned by any other person.

${ }^{14}$ Article 324 stipulates that an organization or individual may, in accordance with the law, possess, use, and seek profits from the natural resources owned by the State, or owned by the State but are used by collectives, or owned by collectives as provided for by laws. Article 328 stipulates that the right to use sea areas that is obtained in accordance with the law shall be protected by law. Article 329 stipulates that the mineral exploration right, the mining right, the water intake right, and the right to use water areas or intertidal zones for aquaculture or fishing, which are obtained in accordance with the law, shall be protected by law.

15 《中华人民共和国物权法》, or the Property Law of the People's Republic of China, was adopted by the National People's Congress in 2007 (on March 16) that went into effect on October 1, 2007. It will be abolished after the Civil Code of the People's Republic of China becomes effective on January 1, 2021.

16 《中华人民共和国担保法》, or the Guaranty Law of the People's Republic of China, was promulgated by the National People's Congress in 1995 (on June 30) that went into effect on October 1, 1995. It will be abolished after the Civil Code of the People's Republic of China becomes effective on January 1, 2021.

17 Article 388 stipulates that for the creation of security interest, a contract on the provision of security shall be entered into in accordance with the provisions of this Code and other laws. Contracts on the provision of security include mortgage contracts, pledge contracts, and other contracts with security functions. A contract on the provision of security shall be an accessory contract to the principal contract on obligations. When the principal contract on obligations is nullified, the contract on the provision of security should also become invalid, except as otherwise provided for by any law. After the nullification of the contract on the provision of security, mistakes, if any, of the debtor, guarantor, or creditor, shall be affixed with due civil responsibilities.
} 
be equally protected by law. ${ }^{18}$

Second, the part on real rights of the Civil Code introduces a concept of land management right to respond to China's land policy and practical needs of the society. ${ }^{19}$

Third, the Civil Code stipulates more clearly that farmers' interests shall be protected when their land is expropriated. It is emphasized that land compensation shall be "paid on time and in full amount", and "rural villagers" house" is specified as an item that requires compensation. ${ }^{20}$ It should also be noted that a new rule is added to provisions on land expropriation to meet urgent needs of epidemic containment. ${ }^{21}$ These special stipulations fully demonstrate that the Civil Code observes the philosophy of putting people first.

Fourth, a provision concerning ownership has been added to the Civil Code that the ownership of the property of legal persons making donations shall be protected by law. ${ }^{22}$ For some time in the past, people had been arguing about the attribution of property rights of some religious sites such as temples and churches. It should be noted that sources of property donated to religious sites are relatively complex. In China, a portion of religious venues are funded by the state and some are financed in the form of donations by organizations or individuals. Under the circumstances, the Civil Code introduces the concept of legal persons making donations and specifies how to ascertain the attribution of property of religious sites. An ensuing question is how to identify the nature of legal persons making donations. In general provisions, legal persons are categorized as for-profit legal persons, non-profit legal persons, and special legal persons. Since the concept of legal persons making donations is not included in general provisions, this concept may not be able to fit into any category of legal persons in general provisions and even conflict with it. To solve these problems, further investigation and improvement are needed.

\footnotetext{
18 Article 113 stipulates that the property rights of the parties to civil legal relations shall be equally protected by law. Article 207 stipulates that the real rights of the State, collectives, individuals, and other right holders shall be equally protected by law, and shall not be infringed upon by any organization or individual.

${ }_{19}$ Article 340 stipulates that the holder of the land management right has the right to occupy land in rural areas, carry out agricultural production and operation independently, and obtain proceeds, during the period as agreed upon in the contract. Article 341 stipulates that the land management right with a circulation period of five years or more shall be created when the circulation contract becomes valid. A party may apply to the registration authority for the registration of the land management right; and if it is not registered, it shall not be set up against a bona fide third party. Article 133 of the Property Law of the People's Republic of China stipulates that where a person enters into a contract for the right to rural land such as barren land through bidding, auction, open consultation or other means, his right to land contractual management may, in accordance with such laws as the Law on Land Contract in Rural Areas and the relevant regulations of the State Council, be circulated through transfer, pooling of rights as shares, mortgage, or other means. This article has been replaced by Article 342 of the Civil Code of the People's Republic of China, which stipulates that where rural land is contracted by bidding, auction, open consultation, or other means, and the certificate of ownership has been obtained upon registration in accordance with the law, the land management right may be legally circulated by leasing, pooling of rights as shares, mortgage, or other means.

${ }^{20}$ Paragraph 2 of Article 243 stipulates that where land owned by collectives is expropriated, land compensation, resettlement subsidies, and compensation for rural villagers' houses, other fixtures on land, and young crops, among others, shall be paid on schedule and in full amount in accordance with the law, and social security expenses for the farmers whose land is expropriated shall be arranged for, in order to guarantee the farmers' daily lives and safeguard their lawful rights and interests.

${ }_{21}$ Article 245 stipulates that in order to meet such urgent needs as emergency rescue, disaster relief, and epidemic containment, the immovables or movables of an organization or individual may be requisitioned within the limits of power and in compliance with the procedures provided for by law. After the use of the requisitioned immovables or movables, they shall be returned to the organization or individual whose immovables or movables are requisitioned. Where the immovables or movables of organizations or individuals are requisitioned or if they are damaged or lost thereafter, compensations shall be made therefore.

22 Article 270 stipulates that the immovables and movables legally owned by social-organization legal persons and endowed legal persons shall be protected by law.
} 
Fifth, the Civil Code deems the right of habitation as a type of real right and hence effectively protects rights and interests of vulnerable groups. ${ }^{23}$

Background of formulation. Back in 2007, when the Property Law of the PRC was being formulated, some academics argued that the right of habitation should be included in this Law. Nonetheless, this proposal aroused considerable controversy and the top legislature made the final decision of not establishing the right of habitation. The Civil Code, conversely, establishes the right of habitation as a new usufruct so as to implement the requirements laid down during the 19th National Congress of the Communist Party of China of putting in place a housing system that ensures supply through multiple sources and provides housing support through multiple channels. This is a highly significant measure to the society because a larger quantity of citizens, once granted the right of habitation, can occupy and use others' housing units so as to stably meet their own needs of living ${ }^{24}$.

Grounds for formulation. It is stipulated in the Civil Code that to create a right of habitation, the parties shall enter into a contract on the right of habitation or that a right of habitation can be created by testament. In general, the creation of the right of habitation is built on agreement. However, can the right of habitation be established by law for people of specific kinship? For example, when a couple is engaged in a conflict in the process of partitioning property and cannot reach a mediation agreement, to settle this dispute, can a court rule that one party enjoys the ownership of their house and the other party owns the right of habitation, or can a court establish the right of habitation through judgement? This question remains to be answered by the Civil Code.

Conditions for the establishment the right of habitation. To create a right of habitation, the parties shall enter into a contract on the right of habitation in a written form. It is universally believed that the right of habitation is a personal servitude, which means that it is created to satisfy needs of a particular person. The right of habitation in other people's housing units and their auxiliary facilities is exclusive, free of charge, non-transferrable, and non-inheritable. It is stipulated in the Civil Code that in principle the creation of the right of habitation shall be free of charge and any practice that makes charges for creating the right of habitation shall only be an exception. For instance, a couple decides to establish the right of habitation after negotiation and grants the right of habitation to one party and the ownership of their housing unit to another party. It is reasonable to infer that they have both made compromises over their joint property, and thus the establishment of the right of habitation is no longer completely free of charge. The author believes that under such

\footnotetext{
23 Article 366 stipulates that as agreed upon in a contract, a person having a right of habitation enjoys the usufruct to occupy and use another's housing unit so as to meet the needs of living. Article 367 stipulates that to create a right of habitation, the parties shall enter into a contract on the right of habitation in a written form. The contract on the right of habitation shall generally include the following clauses: (1) the names or titles, and domiciles of the parties; (2) the location of the housing unit; (3) the conditions and requirements for habitation; (4) the term of the right of habitation; (5) the methods for the resolution of disputes. Article 368 stipulates that the right of habitation shall be created free of charge, unless it is otherwise agreed upon by the parties. If the right of habitation is created, an application for the registration of the right of habitation shall be filed with the registration authority. The right of habitation is created at the time of registration. Article 369 stipulates that the right of habitation shall not be transferred or inherited. A housing unit with the right of habitation created shall not be leased, unless it is otherwise agreed upon by the parties. Article 370 stipulates that the right of habitation is extinguished when the term of the right of habitation expires or the person having the right of habitation deceases. If the right of habitation is extinguished, deregistration shall be undergone in a timely manner. Article 371 stipulates that the relevant provisions of this Chapter shall apply, mutatis mutandis, to the creation of the right of habitation by testament.

${ }^{24}$ Explanatory notes to the Civil Code of the People's Republic of China (draft) made by Wang Chen, vice chairman of the National People's Congress Standing Committee at the third session of the 13th National People's Congress on May 22, 2020.
} 
circumstances, the establishment of the right of habitation to some extent levies charges. Regarding the mission of this piece of legislation, the system of the right of habitation is developed to help satisfy housing needs of dwelling owners' relatives. However, since the Civil Code does not restrict subjects of the right of habitation to relatives, does that mean that other people can also be granted the right of habitation? For example, are babysitters and hired labor entitled to this right?

Sixth, the Civil Code introduces a rule concerning property management service's responsibilities for prevention and control. ${ }^{25}$ This rule is also known as the COVID-19 article because it is imposed to meet the need of containing the COVID-19 epidemic. It is a new duty added to Paragraph 1 of Article 285.

This rule provides for emergency response measures in face of an emergency such as an epidemic, but has also given rise to the following problems: (1) How to ascertain the nature of implementing prevention and control measures? During the COVID-19 pandemic, China has effectively mobilized its communities and villages in epidemic containment. In accordance with government requirements, these community-level units have implemented some emergency measures, such as blocking roads, requesting suspected COVID-19 patients to isolate themselves at home, and curtailing citizens' freedom of movement. Should these measures be viewed as actions authorized by the government or steps taken by property management services in the interest of management? The author is of the opinion that these steps should be classified as actions authorized by the government, otherwise they cannot be protected by law. (2) How to pay for expenses arising out of epidemic prevention and control? Amidst the COVID-19 pandemic, the expenses are covered by the government and so it is in other special occasions. Nevertheless, China has currently normalized COVID-19 prevention and control. Then who should bear expenses of goods and materials needed for normalized prevention and control, and all the human costs that emanate from measures taken and tools employed, and even the deployment of frontline workers? These issues are yet to be clarified and addressed in the Civil Code. (3) How to identify the subject of liability who does not implement prevention and control measures and then leads to serious consequences? For instance, if a suspected COVID-19 patient is admitted to a residential community due to neglect of duty of staff that works for a property management service and results in large-scale infections within that neighborhood, who is supposed to assume the responsibilities? In the light of the abovementioned analysis, it can be concluded that against the background of normalized epidemic prevention and control in China the newly added rule remains to be perfected.

\section{A Separate Part Is Devoted to Personality Rights to Accentuate the Importance of Maintaining Personal Dignity}

The Civil Code espouses the notion of putting people first. It throws the status of people into relief, places people in the most important position, and endeavors to retain personal dignity.

\footnotetext{
${ }^{25}$ Article 285 stipulates that the property management service or any other manager shall, as entrusted by the owners, manage the building and its affixtures within the district of the building according to the provisions of Part Three of this Code governing property management service contracts, be subject to supervision by the owners, and give replies to the inquiries made by the owners on property management services in a timely manner. The property management service or any other manager shall execute the emergency response measures and other management measures legally taken by the government, and actively cooperate in the relevant work.
} 


\section{Reasons for Dedicating a Part to Personality Rights}

Granting personality rights independent status is indeed an exceptional practice in the codification of civil codes around the world. It is peculiar to the Civil Code of the PRC. The Civil Code compiles personality rights in a separate part for the following three reasons.

First, the General Principles of the Civil Law of the $\mathrm{PRC}^{26}$ promulgated in 1986 dedicates a section to personality and personal rights. Chapter 5 of the General Principles of the Civil Law, or the chapter on civil rights first stipulates property rights, creditors' rights, intellectual property rights, and then personality and personal rights. However, although the last section is titled personality and personal rights, its stipulations are mostly about personality rights rather than personal rights. This tradition is then handed down to the Civil Code. Second, personality rights themselves are a type of civil rights. Since other civil rights are devoted separate parts in the Civil Code, personality rights should also deserve one part. Third, if personality rights are stipulated in the part on general provisions, then it will be difficult to detail the provisions because of limited space. On top of that, the biggest highlight of the Civil Code in modern China should be to point up the status of people, vigorously maintain personal dignity, and provide legal protection for people who crave for a good and happy life. It is therefore necessary to create an independent part on personality rights and enrich this part as much as possible.

\section{Significance of Dedicating a Part to Personality Rights}

Whether personality rights should be granted standalone status is the most controversial problem in the history of civil code codification in China. The Chinese top legislature ultimately decides to dedicate a part to personality rights. This move is a major creation and distinctive feature of the Civil Code of the PRC, and is extremely significant.

First, this move is conducive to the establishment of a complete system of personality rights. Personality rights are stipulated in detail in 61 articles of the Civil Code ranging from Article 989 to Article 1039. Personality rights are comprised of 10 types of rights, namely the rights of life, inviolability and integrity of person, health, name, portrait, reputation, honor, privacy, and personal information protection. Second, this move further emphasizes the importance of protecting people's life, bodily integrity and health. Third, this move broadens the scope of personality right and interest protection and retains human dignity to the maximum.

Provisions in the part on personality rights, compared with those in the part on real rights, are relatively simple, rough, and not all-inclusive; therefore legislation regarding personality rights remains to be improved. Some academics argue that it is illogical to include the right of inviolability and integrity of person and the right of health in personality rights (Zhang, 2018). Professor Liang Huixing from the Chinese Academy of Social Sciences, also a renowned civil jurist, strongly opposes devoting an independent part to personality rights. He asserts that some rights stipulated in the Civil Code cannot be exercised like other rights. For example, the rights of life, inviolability and integrity of person, and health are enjoyed as long as others do not infringe them. When these rights are encroached, they can be fully safeguarded by relevant provisions in the part on tort liability. Therefore, there is no need to create a separate chapter on personality rights. Moreover,

26 《中华人民共和国民法通则》, or the General Principles of the Civil Law of the People's Republic of China, was adopted by the National People's Congress in 1986 (on April 12) that went into effect on January 1, 1987. It was later amended on August 27, 2009 and will be abolished after the Civil Code of the People's Republic of China becomes effective on January 1, 2021. 
due to this change the Civil Code of the PRC will significantly deviate from the standard practice in the codification of civil codes around the world.

\section{Benefits From Dedicating a Part to Personality Rights}

To encourage digital innovation, protect personal information, and apply a principle of balanced digital economic development in an era of artificial intelligence, the Civil Code actively embraces personal information, responds to the latest demands, and contributes to the advancement of rule of law in human society by sharing Chinese knowledge and proposing Chinese approaches.

First, dedicating a part to personality rights enables China to actively cope with challenges that stem from rapid development of IT application, and encourages digital innovation. First of all, the general provisions specify that personal information, data and network virtual property are protected. ${ }^{27}$ Second, the part on personality rights stipulates that a natural person's voice belongs to personality interests and shall be protected by law. ${ }^{28}$ Last but not least, the part on tort liability improves rules about cyber tort liability. This is not only beneficial to the protection of personal safety and property rights and interests, but also helps boost the development of the information technology industry. It can therefore be concluded that the Civil Code fully mirrors the need of rule of law in the information era (Hou \& Liu, 2020).

Additionally, some provisions of the Civil Code have further responded to the needs of social development, and scientific advances and technological innovation. In particular, Articles 1006 to 1009 of the part on personality rights stipulate public order and morality to be observed in biomedical research and innovation. Articles 1034 to 1039 lay down basic content of personal information protection and delineate the boundary of personal information protection (Yao, 2020).

Second, by dedicating a part to personality rights, personal information protection and privacy can be strictly differentiated, and an awareness of right protection can be strengthened.

Articles 1034 to 1039 stipulate personal information protection. Nonetheless, provisions on personal information protection can also be observed in the part on personality rights and other parts of the Civil Code. For example, Articles 1029 to 1030 stipulate the relationship between parties to civil legal relations and credit information handlers such as credit rating agencies. ${ }^{29}$ Paragraph 2 of Article 1034 defines privacy but this definition can be extremely controversial. ${ }^{30}$ It should be noted that Chinese law interprets personal information

\footnotetext{
27 Article 111 stipulates that the personal information of a natural person shall be protected by law. Any organization or individual needing to obtain the personal information of other persons shall legally obtain and ensure the security of such information, and shall not illegally collect, use, process, or transmit the personal information of other persons, nor illegally buy, sell, provide, or publish the personal information of other persons. Article 127 stipulates that where any laws provide for the protection of data and online virtual assets, such laws shall apply.

${ }_{28}$ Paragraph 2 of Article 1023 stipulates that the protection of a natural person's voice shall be governed by the relevant provisions on the protection of the right of portrait, mutatis mutandis.

${ }_{29}$ Article 1029 stipulates that a party to civil legal relations may check his or her own credit rating according to the law; and upon discovery of any inappropriateness in credit rating, he or she has the right to raise an objection and request taking of necessary measures such as making corrections and deletion. Credit raters shall conduct inspection in a timely manner, and take necessary measures in a timely manner, where it is verified to be false. Article 1030 stipulates that the relationship between the parties to civil legal relations and credit information handlers such as credit rating agencies shall be governed by the provisions of this Part on the protection of personal information and other relevant laws and administrative regulations.

${ }_{30}$ Paragraph 2 of Article 1034 stipulates that personal information is various information recorded electronically or in other forms that can identify a specific natural person separately or in combination with other information, including a natural person's name, date of birth, identity card number, biological recognition information, address, telephone number, e-mail address, health information, and whereabouts information, among others.
} 
protection in its broad sense, and that means both online and offline personal information shall protected by law. By comparison, the EU General Data Protection Regulation (GDPR) defines personal information as digital personal information. Hence Chinese law provides protection to a wider range of information, spanning both digital information and information recorded in other forms.

There remains considerable controversy surrounding the legislative model of personal information protection. Chapter 6 of the part on personality rights sparks off a debate over two concepts of personal information right and personal information protection. Some people argue for adopting the concept of personal information right in the Civil Code. Some other people, however, contend that personal information protection should be preferred because it is a new mechanism for personality interests that protects personal information in information society more effectively, and that a distinction should be drawn between privacy rights and personal information protection. In the US, personal information protection develops from an expansion of privacy protection. The GDPR of the EU also uses the concept of data protection. In China, personal information protection ranges over a mass of issues. From the perspective of administration of justice, personal information protection in China is a more extensive protection mechanism which combines obligations and rights. To put it in another way, this mechanism reinforces the protection of rights by means of self-regulation and external supervision and regulation.

\section{By Inserting Provisions on Obligations Into Two Parts, It Will Be Easier to Apply the Law and Fully Respect and Safeguard Civil Rights}

In theory, obligation falls into contractual and non-contractual obligations. Non-contractual obligations encompass tort liability, unjust enrichment, and management of the business of another under no obligation. In the Civil Code, contractual obligations are codified in the part on contracts and this part thereby assumes the role of general provisions of the part on the law of obligations. Unjust enrichment and management of the business of another under no obligation are compiled in quasi-contracts, and tort liability is written in the chapter on tort liability. In this way, provisions on obligations are split into two parts and general provisions of the part on the law of obligations are removed. This arrangement is a major hallmark of the Civil Code.

To Make it Easier to Apply the Law, the Civil Code Does not Create General Provisions of the Part on the Law of Obligations

China does not lay down general provisions of the part on the law of obligations because it wants to maintain the integrity of the Contract $\mathrm{Law}^{31}$ ratified in 1999. When Chinese judges and lawyers try cases of disputes over contracts, they only need to look up rules in the Contract Law and they can rule on the vast majority of cases in compliance with the Contract Law. Chinese judges and lawyers will find it very convenient to hear cases because they can solve basically all problems with the assistance of the Contract Law.

If China adopts Germany and Chinese Taiwan's legislative model and creates general provisions of the part on the law of obligations, then the Contract Law will be divided into two parts, namely that the general

31 《中华人民共和国合同法》, or the Contract Law of the People's Republic of China, was adopted by the National People's Congress in 1999 (on March 15) that went into effect on October 1, 1999. It will be abolished after the Civil Code of the People's Republic of China becomes effective on January 1, 2021. 
provisions of the Contract Law will be placed in general provisions of the part on the law of obligations and the rest will be inserted into other sections of the part on the law of obligations. Consequently, judges and lawyers will have to look up relevant laws in two different places. That means adjudicators will be compelled to alter their long-standing habits of studying and settling disputes, and judges and lawyers will be pressured to change their habits of applying laws. Having taken experience of legal practice into full consideration, the top Chinese legislature eventually reached a decision that general provisions of the part on the law of obligations should not be set down, so that it will be easier to apply the law.

\section{The Part on Contracts Functions as General Provisions of the Part on the Law of Obligations}

The Civil Code does not set up general provisions of the part on the law of obligations. Instead, the part on contracts takes on the role of general provisions of the part on the law of obligations. This gives full expression to functionalism of the Civil Code which centers on the part on contracts.

The part on contracts performs the function of general provisions of the part on the law of obligations, and this function finds expression in the following aspects. The Civil Code retains the part on contracts and incorporates rules concerning obligations into that part so that the part can act as general provisions of the part on the law of obligations. The part on contracts consists of 526 articles in three branches, among which 70 articles are newly added. About one third of the new articles are pertinent to the classification of obligations, unjust enrichment and management of the business of another under no obligation, etc. The third branch stipulates obligations produced by unjust enrichment and management of the business of another under no obligation and that in fact enables the part on contracts, especially its general provisions, to act as general provisions of the part on the law of obligations (Wang, 2020).

The Civil Code stipulates rules for performing obligations in general provisions of the part on contracts so that this part can better play the role of general provisions of the part on the law of obligations. These rules are mainly observed in Article $522^{32}$ and Chapter 7 "termination of contractual rights and obligations". Article 557 distinguishes contract rescission (Clause 2) from circumstances under which an obligation shall be terminated (Clause 1) and makes respective stipulations. ${ }^{33}$ Clause 1 of Article 557 can apply to non-contractual obligations.

The general provisions of the part on contracts differentiate creditors' rights and debtors' obligations from contractual rights and obligations, as are stipulated in, for example, Article 556 and Clause 2 of Article $557 .^{34}$ Provisions on nominate contracts have also taken on the role of general provisions of the part on the law of

\footnotetext{
32 Article 522 stipulates that where the parties agree that the debtor shall perform the obligation to a third party, and the debtor fails to perform the obligation to such third party or the performance of the obligation is not in conformity with the agreement, the debtor shall be liable to the creditor for breach of contract. When the law requires or the parties agree that a third party may directly request the debtor to perform the obligation to a third party, if the third party fails to expressly refuse within a reasonable time limit, and the debtor fails to perform the obligation to the third party, or the performance of the obligation is not in conformity with the agreement, the third party may claim liability of the debtor for breach of contract; and the debtor may raise, against the third party, defenses against the creditor.

33 Article 557 stipulates that an obligation shall be terminated under any of the following circumstances: (1) the obligation has been performed; (2) the obligation is offset against another; (3) the debtor legally tenders and deposits the subject matter; (4) the creditor remits the obligation; (5) the obligation is owed to and by the same person; and(6) any other circumstances for termination as stipulated by laws or agreed upon by the parties. When a contract is rescinded, the rights and obligations under the contract shall be terminated.

34 Article 556 stipulates that where contractual rights and obligations are transferred together, the provisions on the transfer of creditor's rights and the transfer of debtor's obligations shall apply.
} 
obligations. The part on contracts also establishes a branch of quasi-contract (the third branch) and includes management of the business of another under no obligation (Chapter 28) and unjust enrichment (Chapter 29) in this branch (Wang, 2020). These unique categorizations and provisions are peculiar to the Civil Code, and are instrumental in protecting the integrity of the general provisions of the Contract Law (Wang, 2020).

\section{Tort Liability Is Devoted a Standalone Part to Completely Respect and Protect Civil Rights}

Another major innovation of the Civil Code is that a part on tort liability is created. Traditionally, civil codes of civil law countries are structured in logical order, namely that reasons for obligations are first explicated. If provisions on tort liability are incorporated in general provisions of the part on the law of obligations, then a system for provisions on tort liability can never be formed and these provisions are bound to be sketchy. The Civil Code therefore dedicates the last part to tort liability, a sequential arrangement that starts from rights and ends with remedy. Such an arrangement is a substantial contribution made by civil codes of civil law countries.

(1) Article 1254 stipulates the liability of causing harm to another person by throwing an object out of a building. ${ }^{35}$ This article has made major revisions to relevant provisions contained in the Tort Liability Law of the $\mathrm{PRC}^{36}$, and hence safeguards people's safety overhead. It also adapts to the needs of a society that abounds with risks, and provides legal guarantee for people who dream of securing a good and safe life.

(2) The Civil Code adds two new grounds for exemption of liability. To fully safeguard civil rights, the part on tort liability has laid out two new grounds for exemption of liability. First, where a participant voluntarily participates in a risky activity and suffers harm caused by another participant, the latter may be exempted from liability. ${ }^{37}$ Second, where a victim takes reasonable measures to protect his or her own lawful rights and interests, this victim may be exempted from liability. ${ }^{38}$ The first ground, or assumption of risk doctrine, is not an invention of civil law countries but originated in the UK and was further developed in the US. An inclusion of this ground shows that the Civil Code conforms to international standards. The second ground

\footnotetext{
${ }^{35}$ Article 1254 stipulates that throwing an object out of a building is prohibited. Where any object thrown out of a building or falling down from a building causes any harm to another person, the tortfeasor shall assume the tort liability according to the law; and if it is hard to determine the specific tortfeasor through investigation, all the users of the building who possibly commit the tort but those who can prove that they are not the tortfeasor shall make indemnity. After making indemnity, the users of the building who possibly commit the tort shall be entitled to be reimbursed by the tortfeasor. A property management service or any other building manager shall take necessary security measures to prevent the circumstances specified in the preceding paragraph; and if the property management service or any other building manager fails to take necessary security measures, it shall assume the tort liability for failure to perform its security obligations in accordance with the law. If the circumstances specified in Paragraph 1 of this Article occur, public security and other authorities shall investigate in accordance with the law in a timely manner and discover the liable person.

36 《中华人民共和国侵权责任法》, or the Tort Liability Law of the People's Republic of China was adopted by the National People's Congress in 2009 (on December 26) that went into effect on July 1, 2010. It will be abolished after the Civil Code of the People's Republic of China becomes effective on January 1, 2021.

37 Article 1176 stipulates that where a voluntary participant in a recreational or sports activity carrying certain risk sustains harm caused by another participant, the victim shall not require the other participant to assume the tort liability, unless the harm is caused intentionally by, or through gross negligence on the part of, the other participant. The liability of the organizer of the activity shall be governed by the provisions of Articles 1198 through 1201 of this Code.

${ }^{38}$ Article 1177 stipulates that where one whose lawful rights and interests are infringed is unable, under pressing conditions, to receive protection from the state authorities in a timely manner, and his or her lawful rights and interests would be irreparably damaged unless measures were immediately taken, the victim may take reasonable measures such as distraining the property of the tortfeasor to the necessary extent of protecting the victim's own lawful rights and interests and shall immediately request the relevant state authorities to take action. Where the victim takes such improper measures that any harm is caused to another person, he or she shall assume the tort liability.
} 
is geared to cope with emergencies, and it protects victims' civil rights in a timely manner and fully demonstrates that the Civil Code puts people in the first place.

(3) Articles 1194 to 1197 house new provisions on the liability of cyber torts. These rules echo the practical demands of an information era, have distinctive features of the era, and fully demonstrate the modernization of the Civil Code.

\section{Conclusions}

Having analyzed the Civil Code's characteristics of the era and of China in detail, and set forth various unique systems, principles and provisions, the following conclusions can be drawn:

First, the Civil Code revolves around rights, indicating that this Code puts people first. Second, the Civil Code's special provisions on the real right system fully safeguard people's property rights and interests. Third, the Civil Code creates a separate part on personality rights so as to give prominence to the importance of maintaining personal dignity. This part adapts to the need of promoting widespread IT application by providing strong legislative and judiciary support. Fourth, the Civil Code builds on the tradition of civil right legislation in China and dedicates two parts respectively to contracts and tort liability. This arrangement makes it more convenient for legal practitioners to apply the law, and can fully respect and safeguard civil rights.

The Civil Code of the PRC is a preliminarily systematized, modern and international civil code that fits the practicalities of the Chinese society, gives expression to people's will and respects people's willingness. The Civil Code's unique philosophy, systems and provisions, as have been scrutinized in the abovementioned text, are what China contributes to the world.

\section{References}

Hou, G. Y., \& Liu, J. L. (2020). The Civil Code: Positioning of its functions, local features and response to needs of the era. The Chinese Procurators, 11, 3-6.

Wang, L. M. (2020). On the function of the contract part of Civil Code in the general provisions of obligation law. Legal Forum, $35(4), 5-12$.

Yao, H. S. (2020). The Civil Code from a perspective of technological innovation. Shanghai Renda, 6, 41.

Zhang, W. X. (2018). The historic positioning and contemporary traits in the coming Civil Code of People Republic of China. Business and Economic Law Review, 1, 1-16. 